\title{
SPHAERIONINI (COLEOPTERA, CERAMBYCIDAE, CERAMBYCINAE): NOVOS TAXONS, SINONIMIA, CHAVES E NOVA COMBINAÇÃO ${ }^{1}$
}

\author{
Ubirajara R. Martins ${ }^{2,4}$ \\ Dilma Solange Napp ${ }^{3}$
}

\begin{abstract}
New taxa described: Neomallocera, gen. n., type-species, Mallocera opulenta Newman, 1841; Protomallocera, gen. n., type-species, Mallocera hilairei Gounelle, 1908; Championa chemsaki, sp. n. (Mexico: Chiapas); Parasphaerion, gen. n., type-species, $\mathbf{P}$. granulosum, $s p$. n. (Suriname); Mephritus quadrimaculatus, $s p$. n. (Bolivia: Cochabamba). M. castaneus, sp. n. (Peru: Pasco); M. fraterculus, sp. n. (Peru: Cajamarca); Nesostizocera suturalis, sp. n. (Peru and Ecuador); Morphaneflus, gen. n., type-species, M. prolixus, sp. n. (Argentina: Salta, Jujuy); Amethysphaerion eximium, sp. n. (Ecuador); A. jocosum, sp. n. (Brazil: Espirito Santo); A. submetallicum, sp. n. (Brazil: Minas Gerais); A. guarani, sp. n. (Paraguay); Aposphaerion punctulatum, sp. n. (Brazil: Amazonas); Pilisphaerion, gen. n., type-species, P. exoticum, sp. n. (Brazil: Pará); Adiposphaerion, gen. n., type-species. A. rubrum, sp. n. (Brazil: Amazonas); Minipsyrassa guanabarina, sp. n. (Brazil: Rio de Janeiro); Sphaerioeme, gen. n., type-species, S. rubristerna, sp. n. (Suriname, Brazil: Goiás, Mato Grosso, Minas Gerais, São Paulo, Paraná); Apoclausirion, gen. n., type-species, A. nigricorne (Brazil: Mato Grosso).

Mallocera pickeli Melzer, 1931 is considered a synonym of M. simplex White, 1853. Psyrassa trinidadensis Gilmour, 1963 is transferred to the genus Amethysphaerion. Keys to the genera related with Mallocera and to the species of Amethysphaerion are added.
\end{abstract}

O material examinado pertence às seguintes instituições: "American Museum of Natural History", Nova York (AMNH); Coleção Karl-Ernst Hüedepohl, Breibrun (CKHB); "Canadian National Collection", Ottawa (CNCO); Departamento de Zoologia, Universidade Federal do Paraná (DZUP); Instituto de Biociências, Universidade Estadual Paulista, Botucatu (IBUB); Instituto Entomológico de Salta, Rosario de Lerma (INESALT); "Muséum National d'Histoire Naturelle”, Paris (MNHN); Museu Nacional, Rio de Janeiro (MNRJ); Museu de Zoologia, Universidade de São Paulo (MZSP); "Rijksmuseum van Natuurlijke Historie", Leiden (RMNL).

As fotografias são de Sérvio Pires Amante e Albino M. Sakakibara, aos quais ficamos penhorados.

1. Contribuição n. 678 do Departamento de Zoologia, UFPR.

2. Museu de Zoologia, Universidade de São Paulo, Caixa Postal 7172, 01051 São Paulo, SP, Brasil e Departamento de Epidemiologia, Faculdade de Saúde Pública, USP.

3. Departamento de Zoologia, Universidade Federal do Paraná, Caixa Postal 3034, 80001 Curitiba, PR, Brasil.

4. Pesquisador do CNPq. 
Seis gêneros desta tribo caracterizam-se pela pubescência elitral densa que, conforme a incidência da luz, constitui desenhos escuros, em geral com contomos irregulares. Esses gêneros distinguem-se:

1. Meso - e metafềmures com espinho apical externo bem desenvolvido . . . . . . 2

Fêmures desarmados, quando muito as abas apicais são ligeiramente projetadas . . 3

2 (1). Extremidades elitrais desarmadas: élitros largos, bem abaulados posteriormente, metafêmures não ultrapassam as extremidades dos élitros; cavidades coxais anteriores levemente angulosas nos lados . . . . . . . Neomallocera, gen. $\mathrm{n}$.

Extremidades elitrais com espinho externo; élitros estreitos, alongados, pouco abaulados posteriormente; metafêmures quase sempre ultrapassam as pontas dos élitros; cavidades coxais anteriores fechadas lateralmente. . . . . . . . .

Appula Thomson

3(1). Olhos finamente granulosos; pro- e mesofêmures longitudinalmente carenados; antenômero IV com menos da metade do comprimento do III e nitidamente mais curto do que o V; abas apicais dos metafêmures aguçadas; élitros abaulados lateralmente perto do ápice . . . . . . . Pseudomallocera Zajciw

Olhos grosseiramente granulosos; fêmures sem carenas; antenômero IV com 2/3 do comprimento do III e subigual ao V; élitros não abaulados lateralmente, estreitados para o ápice. . . . . . . . . . . . . . . 4

4(3). Protórax com tubérculo lateral; tubérculo central do pronoto geralmente bem indicado. . . . . . . . . . . . . . Mallocera A.-Serville

Protórax cilíndrico, sem tubérculo lateral; tubérculo central do pronoto não indicado .................... Protomallocera, gen. $n$.

\section{Neomallocera, gen. n.}

Espécie-tipo: Mallocera opulenta Newman, 1841.

Palpos maxilares pouco mais longos que os labiais. Lobos oculares superiores com cinco fileiras de omatídios, tão distantes entre si quanto ca. três vezes a largura de um lobo. Antenas com onze artículos, o XI apendiculado. Escapo cilíndrico, pouco mais curto que o antenômero IV. Antenômero III apenas mais longo que o IV, sulcado e bicarenado. Espinhos antenais longos em III e IV, curtos em V e VI (₹) ou em V (c). Protórax mais longo que largo, projetado no meio dos lados, constrito anterior e posteriormente. Pronoto com elevações; as basais mais demarcadas. Partes laterais do protórax sem pontuação sexual. Cavidades coxais anteriores levemente angulosas aos lados, abertas atrás. Élitros abaulados perto do ápice; extremidades arredondadas, desarmadas. Fêmures lineares; espinhos apicais: lado interno dos profêmures e lado externo dos mesoe metafêmures. Metatíbias carenadas. Metatarsômero I tão longo quanto II+ III.

\section{Protomallocera, gen. n.}

Espécie-tipo: Mallocera hilairei Gounelle, 1908.

Palpos maxilares com o dobro do comprimento dos labiais. Lobos oculares superiores com cinco fileiras de omatídios, tão distantes entre si quanto $c a$. de três vezes a largura de um lobo. Antenas com onze artículos. Escapo subcilíndrico, mais curto que o antenômero IV. Antenômero III carenado, apenas mais longo que o IV. Espinhos antenais curtos em III-VI. Protórax mais longo do que largo, cilíndrico, com elevação lateral 
pouco notável que não chega a constituir um tubérculo, situada à frente do meio. Pronoto com quatro tubérculos: dois anteriores glabros e dois basais. Partes laterais do protórax sem pontuação sexual. Cavidades coxais anteriores não angulosas lateralmente, abertas atrás. Extremidades elitrais com espinho externo. Metafêmures lineares, desarmados. Metatarsômero I tão longo quanto II+III.

Mallocera simplex White, 1853

Mallocera simplex White, 1853: 113.

Mallocera pickeli Melzer, 1931: 52, est. 10, fig. 3, syn. n.

A comparação do diapositivo do tipo de $M$. simplex com o holótipo de $M$. pickeli, depositado no Museu de Zoologia da Universidade de São Paulo (MZSP), permitiu estabelecer a sinonímia.

\section{Championa chemsaki, sp. n.}

(Fig. 1)

9. Colorido geral preto com leve reflexo esverdeado metálico. Cada élitro com duas faixas ebúmeas elevadas, transversais: uma próxima da sutura pouco-antes do meio e uma perto da margem ao nível do centro. Pubescência branca; no terço apical dos élitros mais concentrada, constitui estreita faixa oblíqua. Na face ventral a pubescência é mais abundante e está mais concentrada na metade posterior do prosterno. Antenas atingem as pontas dos élitros no meio do antenômero X. Antenômero III não carenado, mais longo do que o IV, com espinho apical curto. Antenômero IV mais curto do que o $\mathrm{V}$ com diminuto espinho apical. Pronoto com pontos grandes, irregulares e algo confluentes. Élitros grosseira e irregularmente pontuados em toda a superfície; extremidades cortadas em curva com espinho nos ângulos sutural e externo. Face ventral e fêmures quase lisos.

Dimensões, em mm. Comprimento total, 9,8; comprimento do protórax, 2,2; maior largura do protórax, 1,7; comprimento do élitro, 6,8; largura umeral, 2,3.

Material. México. Chiapas: San Cristobal, 1 \&, 21.V.1969, J.M. Campbell col. (CNCO, holótipo).

Discussão. A presença de faixa ebúrnea no meio dos élitros, segundo a chave para espécies de CHEMSAK (1967), aproxima esta nova espécie de $C$. elegans e $C$. ctenostomoides. Em ambas, entretanto, o pronoto apresenta faixa transversa basal e os élitros têm faixa sutural longitudinal. Além disso, o padrão de distribuição das faixas ebúrneas nos élitros é completamente diverso.

O nome específico é uma homenagem a J.A. Chemsak que reviu o gênero em 1967.

Parasphaerion, gen. $\mathrm{n}$.

Espécie-tipo: Parasphaerion granulosum, sp. n.

Palpos maxilares pouco mais longos que os labiais. Lobos oculares superiores com sete fileiras de omatídios, tão afastados entre si quanto $c a$. de quatro vezes o diâmetro de um lobo. Tubérculos anteníferos projetados. Escapo subcilíndrico, com metade do 
comprimento do antenômero IV. Antenômero III pouco mais curto do que o IV, carenado no lado interno. Espinhos antenais curtos; no macho em III-V. Protórax tão longo quanto largo, desarmado e arredondado aos lados. Pronoto sem tubérculos, finamente granuloso em toda a superfície. Processo prostemal com metade da largura de uma coxa anterior. Cavidades coxais anteriores angulosas nos lados, abertas atrás. Élitros finamente pubescentes e granulosos em toda a superfície, sem pêlos longos; extremidades cortadas em curva com espinho longo externo e o interno mais curto, dirigido para o lado interno. Metafêmures longos, lineares, acuminados na face dorsal, desarmados no ápice. Metatíbias não carenadas. Metatarsômero I mais longo do que II+III.

Discussão. Élitros com pubescência serícea uniforme em toda a superfície e destituídos de manchas ebúmeas aproximam Parasphaerion de Nyssicostylus, Terpnissa, Atharsus, Sphaerion e Mephritus. Nos três primeiros, os metafêmures são pedunculados e clavados e ultrapassam a ponta dos élitros; além disso, os palpos maxilares têm mais do que o dobro do comprimento dos labiais. O novo gênero difere de Sphaerion e de Mephritus pelos fêmures posteriores lineares, pronoto e élitros fina e densamente granulosos em toda a superfície e protórax ( $($ ) tão longo quanto largo, com lados arredondados.

\section{Parasphaerion granulosum, sp. $\mathrm{n}$.}

(Fig. 2)

o. Colorido geral vermelho-acastanhado; cabeça, prosterno e face ventral mais amarelados. Fronte e vértice lisos, finamente pubescentes. Antenas muito longas, atingem o ápice dos élitros no meio do antenômero VI, com densa pilosidade sexual no lado inferior dos segmentos. Escapo rugoso. Partes laterais do protórax e prosterno com escultura igual à do pronoto. Face ventral finamente pubescente. Pró- e mesofêmures comprimidos com face superior acuminada, pêlos curtos, escuros e rijos.

Dimensões, em mm. Comprimento total, 23,1; comprimento do protórax, 4,5; maior largura do protórax, 4,8; comprimento do élitro, 10,6; largura umeral 5,2.

Material. Suriname. Zuidgrens Apisiké, 1 ó, 21.IV.1952, D.C. Geijkes col. (RMNL, holótipo).

\section{Mephritus quadrimaculatus, sp. $\mathrm{n}$.}

đ. Cabeça e protórax avermelhados. Élitros vermelho-alaranjados com a região circum-escutelar escurecida em pequena extensão; pouco atrás do meio, em cada élitro, duas manchas acastanhadas, pequenas, ovais (a interna pouco mais posterior). Antenômero III sem sulcos ou carenas. Espinhos antenais em III-VI. Pronoto com cinco tubérculos, situados do nível do terço anterior para trás; uma gibosidade adicional, entre os laterais e situada mais extemamente; tubérculo centro-basal longitudinal, acuminado no lado anterior. Tubérculo centro-lateral do protórax acuminado; uma gibosidade glabra entre esse tubérculo e a orla anterior. Superfície pronotal pontuada, mais finamente no terço anterior. Escutelo com pubescência dourada, densa. Élitros pubescentes em toda a superfície, com pêlos curtos, abundantes; extremidades cortadas em curva com espinho externo. Fêmures lisos, pubescentes. Metatíbias não carenadas.

Dimensões, em mm. Comprimento total, 14,6; comprimento do protórax, 2,8; maior largura do protórax, 3,0; comprimento do élitro, 10,3; largura umeral, 3,4.

Material. Bolívia. Prov. Cochabamba, 1 ơ, 1889, P. Germain col. (NHN, holótipo).

Discussão. $O$ padrão de colorido dos élitros é único e distingue $M$. quadrimaculatus de todas as outras espécies. Além disso, o pronoto apresenta praticamente sete gibosidades e os lados do protórax, além do espinho central, uma gibosidade anterior. 

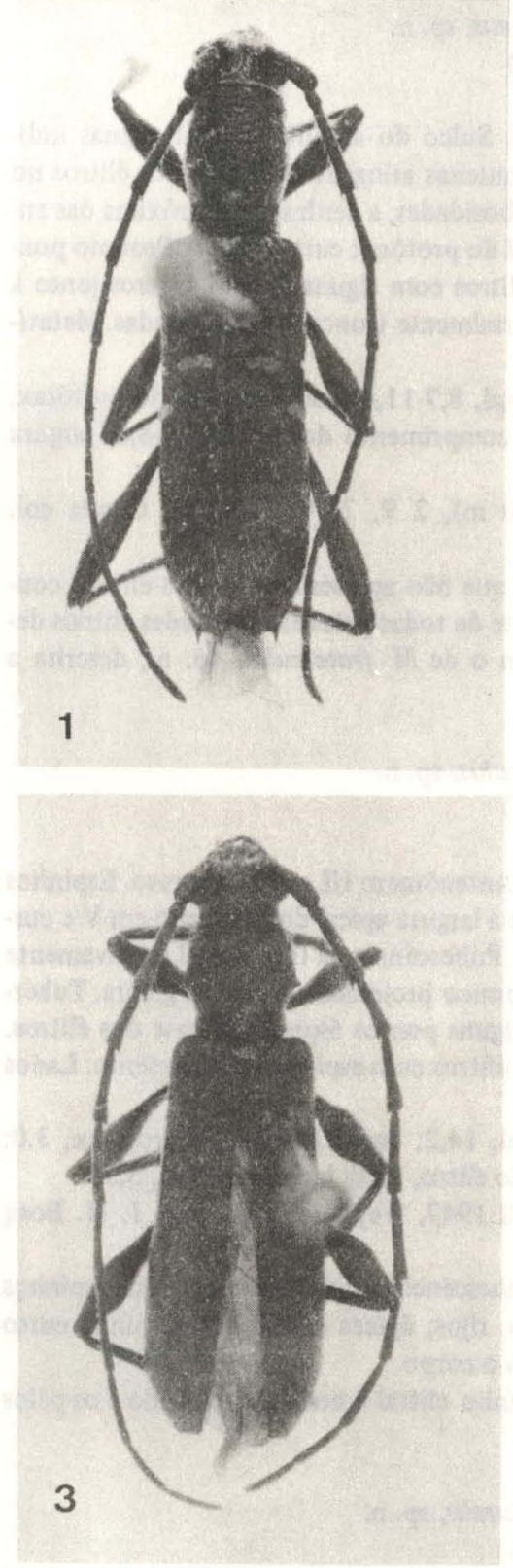
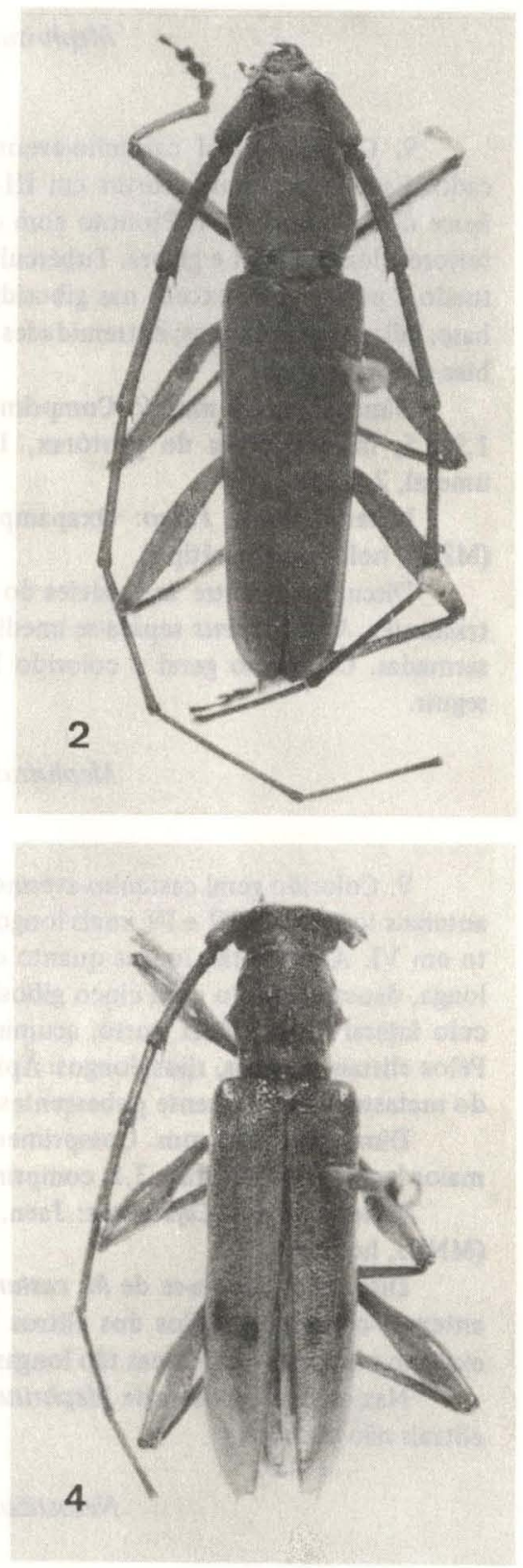

Figs. 1-4. 1, Championa chemsaki, sp.n., holótipo $\uparrow ; 2$, Parasphaerion granulosum, sp.n., holótipo $\delta$; 3 , Mephritus castaneus, sp.n., holótipo $\subsetneq ; 4$, Mephritus quadrimaculatus, sp.n., holótipo ơ. 


\section{Mephritus castaneus, sp. $\mathrm{n}$.}

(Fig. 3)

§. Colorido geral castanho-avermelhado. Sulco do antenômero III apenas indicado. Espinhos antenais curtos em III-V. As antenas atingem as pontas dos élitros no ápice do antenômero $\mathrm{X}$. Pronoto com cinco gibosidades, a central mais próxima das anteriores, longitudinal e glabra. Tubérculo lateral do protórax curto, agudo. Pronoto pontuado e pubescente, exceto nas gibosidades. Élitros com alguns pontos ásperos junto à base; pélos elitrais longos; extremidades transversalmente truncadas, desarmadas. Metatíbias não carenadas.

Dimensōes, em mm, ?. Comprimento total, 8,7-11,4; comprimento do protórax, 1,9-2,5; maior largura do protórax, 1,9-2,5; comprimento do élitro, 6,0-8,0; largura umeral, 2,2-2,8.

Material. Peru. Pasco: Oxapampa (1800 m), 2 \&, 28.VI.1966, R. Garcia col. (MZSP, holótipo e parátipo).

Discussão. Dentre as espécies do gênero que não apresentam pontos elitrais contrastantes, $\boldsymbol{M}$ castaneus separa-se imediatamente de todas pelas extremidades elitrais desarmadas. $\mathrm{O}$ aspecto geral e colorido lembram o de $M$. fraterculus, $\mathrm{sp}$. $\mathrm{n}$., descrita a seguir.

\section{Mephritus fraterculus, sp. $\mathrm{n}$.}

(Fig. 5)

१. Colorido geral castanho-avermelhado. Antenômero III com sulco raso. Espinhos antenais longos em III e IV, mais longo do que a largura apical do segmento em V $\epsilon$ curto em VI. Antenas tão longas quanto o corpo. Pubescência da face dorsal relativamente longa, densa. Pronoto com cinco gibosidades pouco projetadas, a central glabra. Tubérculo lateral do protórax curto, acuminado. Alguns pontos ásperos na base dos élitros. Pêlos elitrais brancos, rijos, longos. Ápices dos élitros com espinho curto externo. Lados do metasterno densamente pubescentes.

Dimensões, em mm. Comprimento total, 14,2; comprimento do protórax, 3,0; maior largura do protórax, 3,1; comprimento do élitro, 10,0; largura umeral, 3,3.

Material. Peru. Cajamarca: Jaen, 1 \&, III.1947, Weyrauch col., Col. J. M. Bosq (MNRJ, holótipo).

Discussão. Separa-se de $M$. castaneus: pubescência corporal longa, densa; espinhos antenais compridos; pêlos dos élitros brancos, rijos; ápices elitrais com espinho curto externo e antenas das fêmeas tão longas quanto o corpo.

Nas demais espécies de Mephritus o espinho elitral é bem desenvolvido e os pêlos elitrais não são rïjos.

Nesostizocera suturalis, sp. n.

(Fig. 6)

Cabeça, protórax e face ventral pretos ou castanho-escuros. Antenas e pernas amarelo-alaranjadas. Élitros amarelo-alaranjados com friso sutural e espinho apical pretos. Em um dos exemplares (\$) os élitros apresentam manchas pretas: uma longitudinal que se inicia entre o escutelo e o úmero, volta-se e alarga-se em direção à sutura alcançando-a 
ao rível do terço anterior; o contorno posterior dessa mancha é irregular e denteado; na metade apical de cada élitro mais duas manchas longitudinais, uma mais anterior e mais curta perto da margem e uma posterior sobre a declividade lateral. Cabeça e pronoto com pubescência esbranquiçada. Escutelo e face ventral pubescentes. Élitros com numerosos pêlos curtos em toda a superfície, entremeados por pêlos longos, esparsos, mais ou menos organizados em fileiras. Antenas atingem o ápice elitral no meio do antenômero VIII ( $\left(^{\circ}\right)$ ou têm ca. o mesmo comprimento do corpo (\$). Espinhos antenais em III-V, o do III longo. Extremidades elitrais cortadas em curva com espinho externo. Abas apicais dos mesofêmures aguçadas e com comprimentos subiguais. Extremidades dos metafêmures com dois espinhos curtos, o externo um pouco mais longo.

Dimensões, em mm, respectivamente ठैe \&. Comprimento total, 13,1-14,4 e 16,2; comprimento do protórax, 2,5-2,9 e 3,2; maior largura do protórax, 2-2,7; comprimento do élitro, 9,6-10,2 e 12,2; largura umeral, 3,1-3,4 e 3,5.

Material. Peru. 1 ơ(CKHB, parátipo); Q. Chinche $(1500 \mathrm{~m}), 1$ \%, 15.III.1975, I. Ascencios col. (MZSP, parátipo). Equador. Durancambos (?), 1 o, Col. J. M. Bosq (MNRJ, holótipo).

Discussão. $N$. suturalis difere das demais espécies sulamericanas pela sutura elitral preta.

Morphaneflus, gen. n.

Espécie-tipo: Morphaneflus prolixus, sp. $\mathrm{n}$.

Palpos maxilares pouco mais longos que os labiais. Lobos oculares superiores com cinco fileiras de omatídios, tão distantes entre si quanto a largura de um lobo. Antenas com onze artículos, desarmadas, ultrapassam as pontas dos élitros. Escapo cilíndrico, mais curto que o antenômero IV. Antenômero III tão longo quanto o IV, não carenado. Protórax subcilíndrico, pouco mais longo do que largo, desarmado aos lados. Pronoto sem tubérculos. Processo prosternal sublaminiforme. Cavidades coxais anteriores não angulosas lateralmente, abertas atrás. Élitros sem pubescência, com pêlos curtos, deitados, em toda a superfície; extremidades entalhadas em curva com os ângulos apenas projetados. Metafêmures lineares, desarmados. Metatarsômero I tão longo quanto II+III.

Discussão. Antenas desarmadas e élitros destituídos de pubescência serícea aproximam este gênero de: Etymosphaerion (cujas antenas têm doze segmentos), Eurysthea e algumas espécies de Amethysphaerion. Difere de Eurysthea pela ausência de tubérculos pronotais e de Amethysphaerion pelas antenas não carenadas, ápices dos élitros desarmados e pilosidade pronotal e elitral.

$\mathrm{O}$ aspecto geral de $\boldsymbol{M}$ prolixus lembra muito o das espécies do gênero Aneflomorpha que ocorrem nas Américas do Norte e Central e que apresentam o antenômero III espinhoso.

\section{Morphaneflus prolixus, sp. $\mathrm{n}$.}

(Fig. 7)

¿t(?). Colorido geral avermelhado; fêmures mais escuros, castanho-avermelhados. Face dorsal com pêlos brancos, curtos, deitados; a ventral com pilosidade mais densa. Antenômeros III-VI com alguns pêlos longos, esparsos, no lado interno. Escutelo densamente pubescente. Cabeça pontuada. Pronoto pontuado com área centro-basal longitudinal lisa e glabra. Pontuação da base dos élitros e dos lados do protórax semethante à do pronoto. Metatíbias finamente carenadas. 
Dimensōes em mm (ס'?). Comprimento total, 8,2-8,6; comprimento do protórax, 1,4-1,5; maior largura do protórax, 1,2-1,3; comprimento do élitro, 5,9-6,9; largura umeral, 1,5-1,6.

Material. Argentina. Salta; Dep. San Martin (Dique Itiyon), 1 (§?), XII.1970, Col. A. Martinez (INESALT, parátipo). Jujuy: Termas del Palmar, 1 ( ${ }^{*}$ ?), 9.I.1950, A. Martinez col. (MZSP, holótipo).

\section{Amethysphaerion Martins \& Monné, 1975}

Amethysphaerion Martins \& Monné, 1975: 290.

Chave para as espécies:

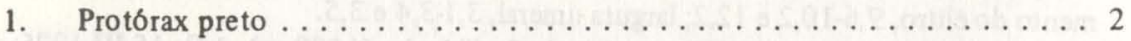

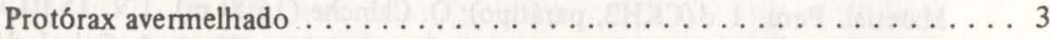

2(1). Élitros castanho-avermelhados, escuros; pernas pretas; pronoto liso. Equador . . . . . . . . . . . . . . .

Élitros amarelo-alaranjados com extremidades pretas; pernas avermelhadas, exceto ápices dos fêmures; pronoto pontuado. Brasil (Espírito Santo) . . . . . .

jocosum, sp. n.

3(1). Antenômero III desarmado ou com espinho diminuto; antenômero IV desarma-

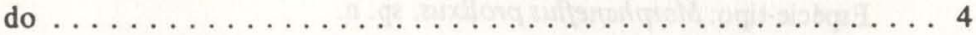

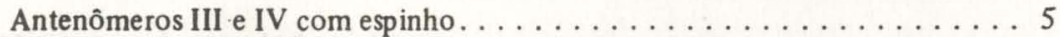

4(3). Élitros pretos com leve reflexo metálico. Brasil (Minas Gerais) . . . . . . submetallicum, sp. $\mathrm{n}$.

Élitros avermelhados com extremidades pretas. Paraguai....... guarani, sp. n. 5(3). Comprimento, 10,5 mm; extremidades elitrais obliquamente truncadas com espinho externo tão longo quanto o metatarsômero I e espinho sutural bem projetado, tão longo quanto o antenômero II. Bolívia. Brasil (São Paulo) . . . . . ................... nigripes Martins \& Monné

Comprimento, $8,3 \mathrm{~mm}$; extremidades elitrais cortadas ém curva, com espinho externo mais curto do que o metatarsômero I e espinho sutural mais curto que $\mathrm{o}$ antenômero II. Trinidad y Tobago, Venezuela

trinidadensis (Gilmour)

Amethysphaerion eximium, sp. $\mathrm{n}$.

(Fig. 8)

ठ. Cabeça, escapo, élitros e pernas, pretos; protórax e face ventral preto-avermeIhados; antenas castanho-avermelhadas, mais claras para as extremidades. Lobos oculares superiores largos, com seis fileiras de omatídios, tão distantes entre si quanto metade da largura de um lobo. Antenas atingem o ápice elitral no meio do antenômero IX. Escapo cilíndrico, mais curto que o antenômero IV. Antenômero III não carenado, mais longo do que o IV, com espinho apical evidente. Espinho do antenômero IV pequeno e o do V diminuto. Protórax pouco mais longo do que largo, abaulado lateralmente atrás do meio. Pronoto sem elevações, liso, brilhante, com apenas raros pontos. Élitros pontuados em toda a superfície com pêlos muito curtos, deitados, na metade posterior; extremidades obliquamente truncadas com espinho externo e sutural. Metasterno e abdômen pontuados. Metafêmures lineares. Metatíbias carenadas. Metatarsômero I mais longo do que II+ III. 
Vol. 7(4), 1990
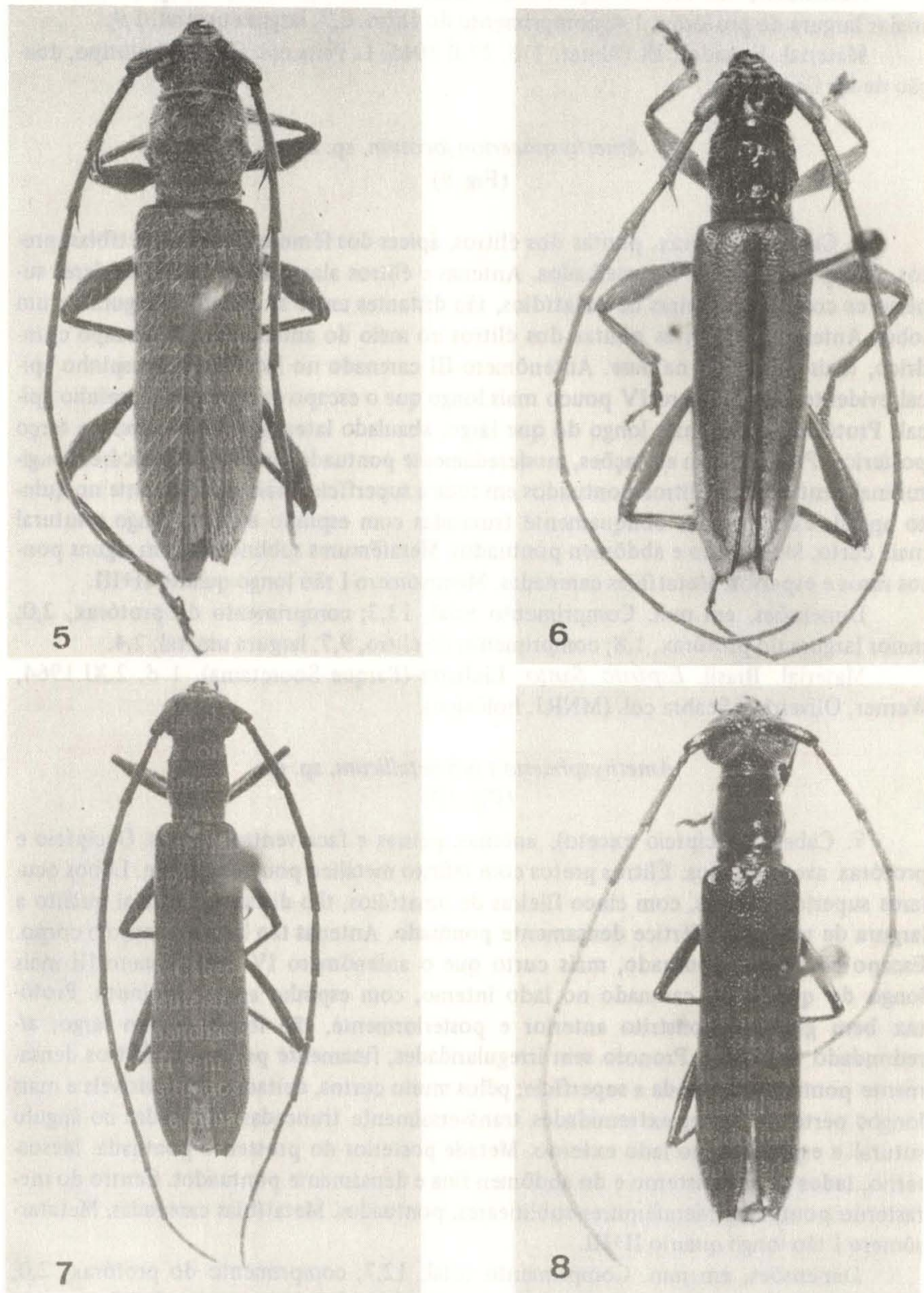

Figs. 5-8. 5, Mephritus fraterculus, sp.n., holótipo $\$ ; 6$, Mesostizocera suturalis, sp.n., parátipo $\delta$; 7, Morphaneflus prolixus, sp.n., holótipo; 8, Amothy sphaerion eximium, sp.n., holótipo o. 
Dimensões, em mm. comprimento total, 9,4; comprimento do protórax, 1,6; maior largura do protórax, 1,4; comprimento do élitro, 6,7; largura umeral, $1,9$.

Material. Equador. El Palmar, 1 đ, 27.II.1965, L. Péña col. (MZSP, holótipo, doação de M. Cerda).

Amethysphaerion jocosum, sp. n.

(Fig. 9)

চ. Cabeça, protórax, pontas dos élitros, ápices dos fêmures e bases das tíbias, pretos. Escapo e fêmures avermelhados. Antenas e élitros alaranjados. Lobos oculares superiores com cinco fileiras de omatídios, tão distantes entre si quanto a largura de um lobo. Antenas atingem as pontas dos élitros no meio do antenômero X. Escapo cilíndrico, mais pontuado na base. Antenômero III carenado no lado interno; espinho apical evidente. Antenômero IV pouco mais longo que o escapo com pequeno espinho apical. Protórax apenas mais longo do que largo, abaulado lateralmente ao nível do terço posterior. Pronoto com elevações, moderadamente pontuado, exceto em uma área longitudinal centrobasal. Élitros pontuados em toda a superfície, mais esparsamente no quinto apical; extremidades obliquamente truncadas com espinho externo longo e sutural mais curto. Metasterno e abdômen pontuados. Metafêmures sublineares com alguns pontos rasos e esparsos. Metatíbias carenadas. Metarsômero I tão longo quanto II+III.

Dimensões, em mm. Comprimento total, 13,2; comprimento do protórax, 2,0; maior largura do protórax, 1,8; comprimento do élitro, 9,7; largura umeral, 2,4.

Material. Brasil. Espirito Santo: Linhares (Parque Sooretama), 1 ó, 2.XI.1964, Werner, Oliveira \& Seabra col. (MNRJ, holótipo).

\section{Amethysphaerion submetallicum, sp. $\mathrm{n}$.}

(Fig. 10)

ๆ. Cabeça (occipício exceto), antenas, pernas e face ventral, pretas. Occipício e protórax avermelhados. Élitros pretos com reflexo metálico pouco aparente. Lobos oculares superiores largos, com cinco fileiras de omatídios, tão distantes entre si quanto a largura de um lobo. Vértice densamente pontuado. Antenas tão longas quanto o corpo. Escapo cilíndrico, pontuado, mais curto que o antenômero IV. Antenômero III mais longo do que o IV, carenado no lado interno, com espinho apical diminuto. Protórax bem globoso, constrito anterior e posteriormente, tão longo quanto largo, arredondado aos lados. Pronoto sem irregularidades, finamente pontuado. Élitros densamente pontuados em toda a superfície; pellos muito curtos, deitados, mais visíveis e mais longos perto do ápice; extremidades transversalmente truncadas, denteadas no ângulo sutural e espinhosas no lado externo. Metade posterior do prosterno pontuada. Mesosterno, lados do mestasterno e do abdômen fina e densamente pontuados. Centro do metasterno pontuado. Metafêmures sublineares, pontuados. Metatíbias carenadas. Metatarsômero I tão longo quanto II+III.

Dimensões, em mm. Comprimento total, 12,7; comprimento do protórax, 2,0; maior largura do protórax, 1,9; comprimento do élitro, 9,7; largura umeral, 2,5.

Material. Brasil. Minas Gerais: Buritís (Ribeirão Confins), 19, 29-31.X.1964, Exp. Dep. Zool. col. (MZSP, holótipo). 

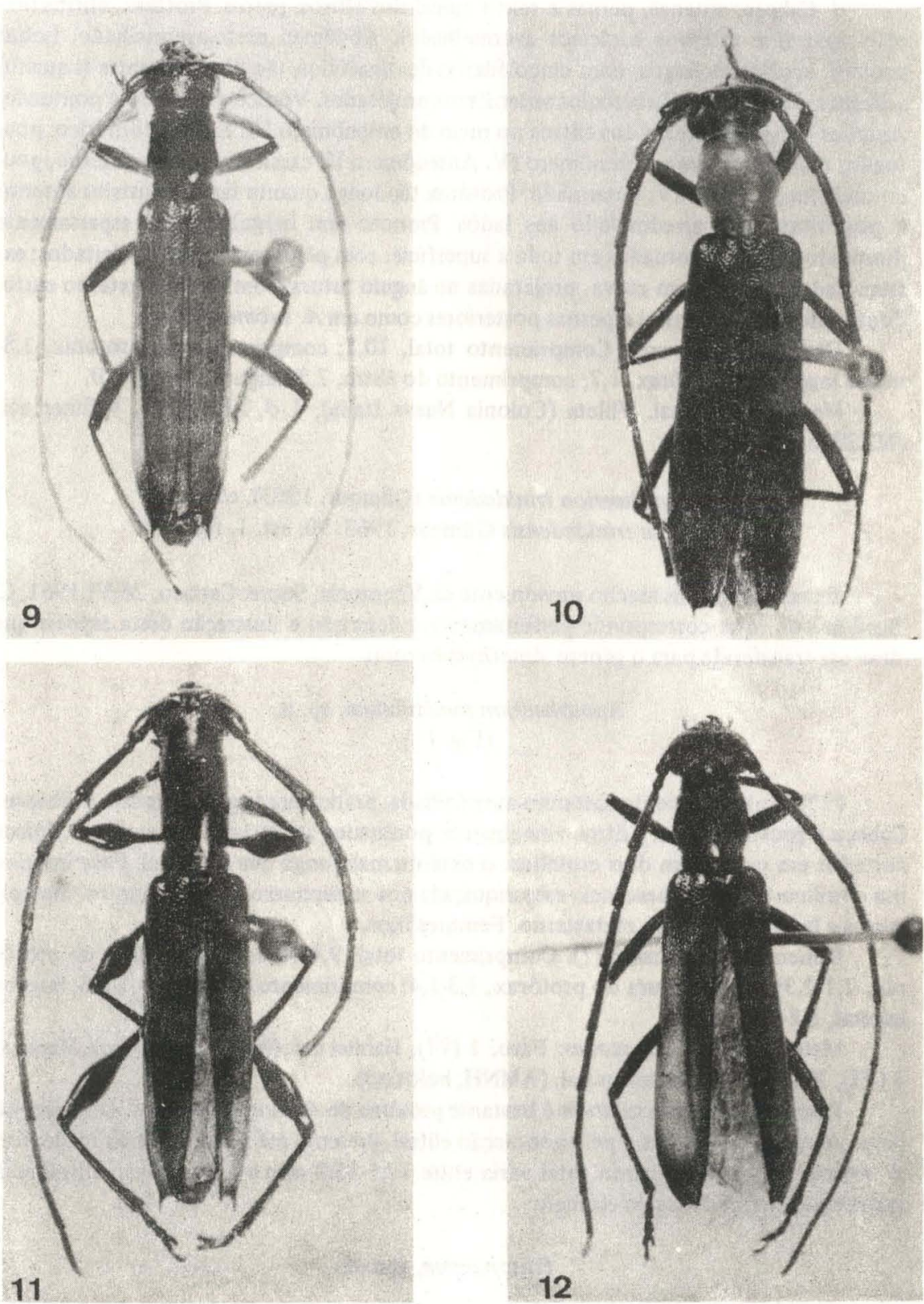

Fiss. 9-12. 9, Amethysphaerion jocosum, sp.n., holótipo $\delta ; 10$, Amethy sphaerion submetallicum, sp.n., holótipo $₹ ; 11$, Aposphaerion punctulatum, sp.n., holótipo; 12, Amethy sphaerion guarani, sp.n., holótipo o. 
đ. Cabeça, antenas, pernas e sexto apical dos élitros, pretos. Protórax, élitros (exceto ápices) e esternos torácicos avermelhados. Abdômen preto-avermelhado. Lobos oculares superiores largos, com cinco fileiras de omatídios, tão distantes entre si quanto a largura de um lobo. Tubérculos anteníferos projetados. Vértice densamente pontuado. Antenas atingem o ápice dos élitros no meio do antenômero IX. Escapo cilíndrico, pontuado, mais curto que o antenômero IV. Antenômero III carenado no lado interno, pouco mais longo que o IV, desarmado. Protórax tão longo quanto largo, constrito anterior e posteriormente; arredondado aos lados. Pronoto sem irregularidades, esparsamente pontuado. Élitros pontuados em toda a superfície, com pêlos muito curtos, deitados; extremidades cortadas em curva, projetadas no ângulo sutural com espinho externo curto. Pontuação da face ventral e pernas posteriores como em $A$. submetallicum.

Dimensões, em mm. Comprimento total, 10,1; comprimento do protórax, 1,8; maior largura do protórax, 1,7; comprimento do élitro, 7,3; largura umeral, 2,0.

Material. Paraguai. Villeta (Colonia Nueva Italia), 1 ó, XI-XII, Pe. Williner col. (MZSP, holótipo).

Amethysphaerion trinidadense (Gilmour, 1963), comb. $n$. Psyrassa trinidadensis Gilmour, 1963: 90, est. 1, fig. 4

Examinamos um macho proveniente de Venezuela, Sucre: Cariaco, 26.VI.1961, C. Bordon col., que corresponde perfeitamente à descrição e ilustração desta espécie que deve ser transferida para o gênero Amethysphaerion.

Aposphaerion punctulatum, sp. $\mathrm{n}$.

(Fig. 11)

(₹?). Uniformemente castanho-avermelhada, praticamente glabra, muito brilhante. Cabeça e protórax lisos. Élitros visivelmente pontuados até quase a extremidade; ápices cortados em curva com dois espinhos: o extemo mais longo que o sutural. Face inferior lisa e brilhante com pubescência esbranquiçada nos mesepimeros, mesepisternos, metepimeros e lado posterior do metasterno. Fêmures lisos.

Dimensōes, em mm, (९?). Comprimento total, 9,4-10,0; comprimento do protórax, 2,1-2,3; maior largura do protórax, 1,3-1,4; comprimento do élitro, 6,1-6,6; largura umeral, 1,8-2,0.

Material. Brasil. Amazonas: Färo, 1 (१?), Hahnel col. (MNHN, parátipo). Manaus, 1 (\$?), X.1945, W. Praetorius col. (AMNH, holótipo).

Discussão. A. punctulatum é bastante próxima de $A$. longicolle Bates. Distingue-se pelas menores dimensões e pela pontuação elitral, presente até quase a extremidade. Em A. longicolle o comprimento total varia entre $12,5-15,0 \mathrm{~mm}$ e a pontuação elitral está restrita às proximidades do escutelo.

Pilisphaerion, gen. n.

Espécie-tipo: Pilisphaerion exoticum, sp. n.

Palpos maxilares pouco mais longos que os labiais. Lobos oculares superiores estreitos, com cinco fileiras de omatídios, tão afastados entre si quanto ca. três vezes a largura de um lobo. Antenas com onze artículos. Escapo subcilíndrico, tão longo quanto o 
antenômero IV. Antenômero III com quase o dobro do comprimento do IV, bicarenado. Espinhos antenais no lado interno de III-VIII e, mais curtos, também no lado externo dos mesmos antenômeros (\$). Protórax mais longo do que largo, com tubérculó lateral ao nível do terço posterior e acentuadamente adelgaçado junto à orla anteriór. Pronoto com três áreas glabras: duas látero-anteriores e uma centro-posterior. Cavidades coxais anteriores angulosas lateralmente, abertas atrás. Escutelo e sexto basal dos élitros com pubescêncią serícea. Élitros com apenas pêlos longos, esparsos; extremidades cortadas em curva, espinhosas no ângulo externo e denteadas no ângulo sutural. Metafêmures pedunculados e clavados, desarmados. Metatarsômero I tão longo quanto II+III.

Discussão. Por apresentar metafêmures pedunculados e clavados, escapo sem cicatriz e protórax com tubérculo lateral, Pilisphaerion aproxima-se de Conosphaerion, $\mathrm{Pe}$ riboeum e Rhomboidederes. Nestes três gêneros os élitros não apresentam pubescência no sexto basal dos élitros e, nos dois primeiros o pronoto tem pontuaçāo aureolada. Escultura pronotal e posição do tubérculo lateral do protórax são caracteres adicionais para distinguir Pilisphaerion e Periboeum.

\section{Pilisphaerion exoticum, sp. $\mathrm{n}$.}

(Fig. 17)

9. Colorido geral castanho-avermelhado; antenas e pernas amareladas. Fronte lisa no centro, rugosa aos lados, com faixas laterais de pubescência esbranquiçada, densa, convergentes para o occipício. Antenas atingem o ápice dos élitros na ponta do antenômero IX, providas de pêlos longos e esparsos que também estão presentes nos fêmures e nas tíbias. Pronoto fina e muito densamente pontuado, pubescente, com três áreas glabras, lisas e brilhantes: duas látero-anteriores transversais e uma centro-basal longitudinal. Élitros finamente pubescentes no sexto basal, moderadamente pontuados até o terço posterior. Mesepisternos, extremidade distal dos metepisternos e orla posterior do metasterno, pubescentes. Restante da face inferior lisa e brilhante.

Dimensōes, em mm. Comprimento total, 9,4; comprimento do protórax, 2,3; maior largura do protórax, 2,0; comprimento do élitro, 5,9; largura umeral, 2,2.

Material. Brasil. Pari: Óbidos, 1 ๆ, VII.1960, Museu Dirings (MZSP, holótipo).

Adiposphaerion, gen. n.

Éspécie-tipo: Adiposphaerion rubrum, sp. n.

Palpos maxilares pouco mais longos do que os labiais. Lobos oculares superiores com seis fileiras de omatídios tão distantes entre si quanto quatro vezes a largura de um lobo. Antenas (\%) com onze artículos, atingem o quarto apical dos élitros. Escapo pouco e gradualmente engrossado para o ápice, tão longo quanto o antenômero IV, longitudinalmente sulcado. Espinhos antenais no lado interno da extremidade de III-VI. Protórax mais largo do que longo, com tubérculo lateral arredondado no topo e situado ao nível do meio. Pronoto com cinco gibosidades pouco demarcadas. Cavidades coxais anteriores apenas angulosas lateralmente, abertas atrás. Processo prosternal tâo largo quanto metade da largura de uma coxa anterior. Escutelo esparsamente pubescente. Élitros com apenas pêlos longos, sem pubescência; extremidades arredondadas e desarmadas. Metafêmures gradualmente engrossados para a clava, desarmados. Mt tatarsômero I tão longo quanto II+III. 
Revta bras. Zool.
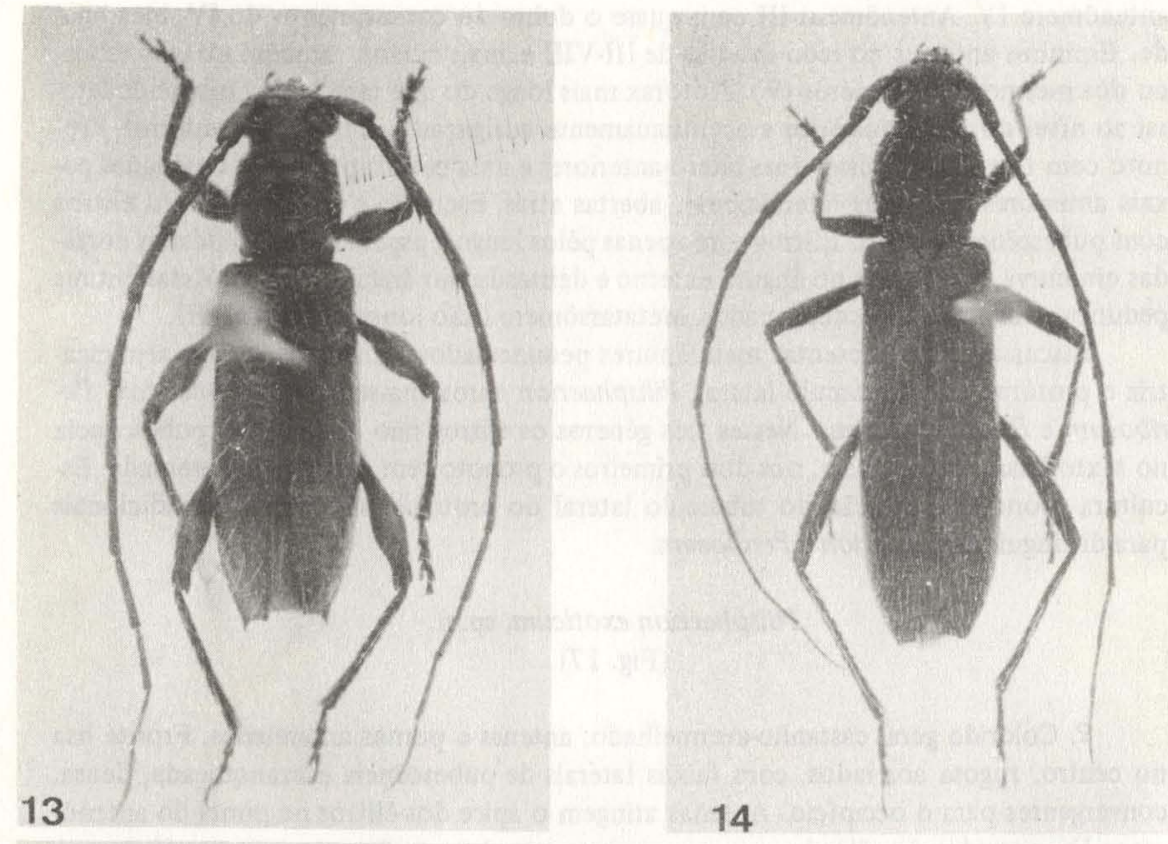

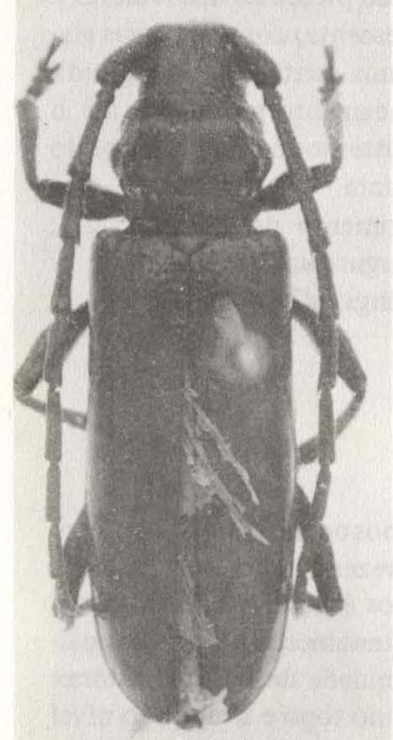

15
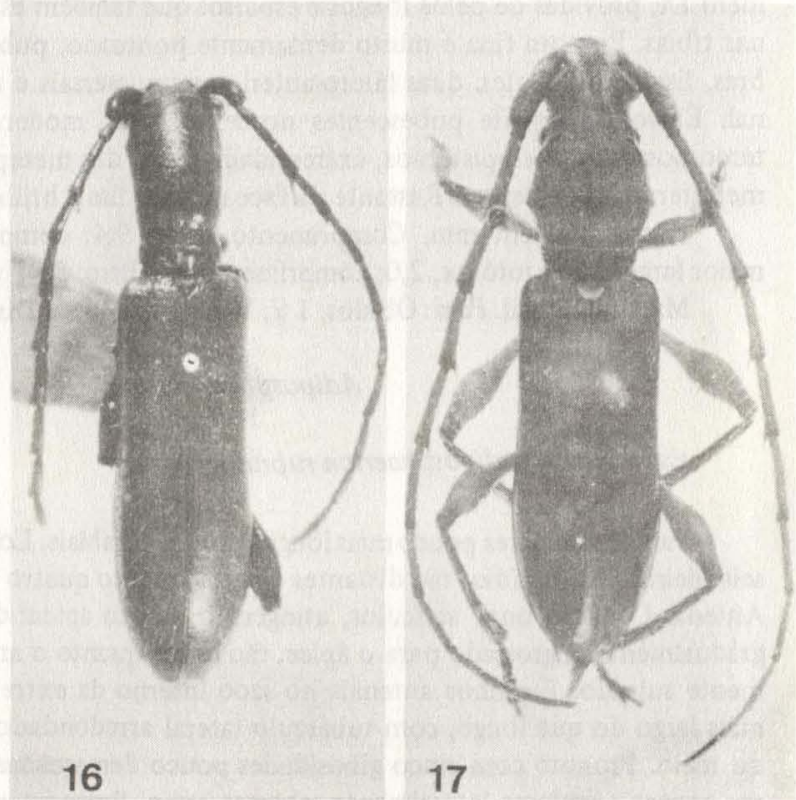

Figs. 13-17. 13, Apodausirion nigricorne, sp.n., holótipo $\delta ; 14$, Sphaerioeme rubristerna, sp.n., holótipo ठ; 15, Adiposphaerion rubrum, sp.n., holótipo \&; 16, Minipsyrassa guanabarina, sp.n., holótipo; 17, Pilisphaerion exoticum, sp.n., holótipo . 
Discussão. Adiposphaerion, gen. n., aproxima-se mais de Periboeum mas separa-se: aspecto geral compacto, robusto; tubérculo lateral do protórax arredondado no topo; extremidades elitrais desarmadas; tubérculos pronotais muito pouco projetados e espinhos antenais curtos.

\section{Adiposphaerion rubrum, sp. $\mathrm{n}$.}

(Fig. 15)

ๆ. Colorido geral àvermelhado. Antenas, fêmures, tíbias, tarsos e estreita região dos ápices dos élitros, pretos. Cabeça lisa. Pronoto com apenas alguns pontos rasos ao lado da gibosidade central. Élitros pontuados na metade basal. Fêmures e face ventral lisos. Pubescência esbranquiçada, esparsa, nos esternos mesotorácicos, metepisternos e regiões látero-posteriores do metasterno.

Dimensões, em mm. Comprimento total, 17,8; comprimento do protórax, 3,1; maior largura do protórax, 4,3; comprimento do élitro, 12,8; largura umeral, 5,2.

Material. Brasil. Amazonas: Manaus, 1 \&, VIII.1941, A. Parko col. (MNRJ, holótipo).

\section{Minipsyrassa guanabarina, sp. $\mathrm{n}$.}

(Fig. 16)

( $\delta$ ?). Colorido geral avermelhado; bases das antenas pouco mais escuras; clavas dos fêmures e grande extensão das tíbias, pretas. Olhos salientes, sem lobos superiores. Vértice e uccipício pontuados. Espinho do antenômero III longo, com ápice rombo; o do IV agudo com ca. metade do comprimento do III; demais antenômeros desarmados. Protórax cilíndrico com lados ligeiramente convergentes para a constrição basal. Pronoto com escultura fina, pouco aparente. Élitros acobertam os metepisternos, pontuados na metade anterior, extremidades arredondadas e desarmadas. Metasterno esparsamente pontuado.

Dimensões, em mm. Comprimento total, 5,1; comprimento do protórax, 1,3; maior largura do protórax, 0,8; comprimento do élitro, 3,5; largura umeral, 1,1.

Material. Brasil. Rio de Janeiro: Rio de Janeiro, 1 (ठ゚?), XI, Acc. n? 2966 (ICCM, holótipo).

Discussão. Além do colorido, difere de $\boldsymbol{M}$. bicolor Martins pelo antenômero IV espinhoso no ápice e pelo metasterno pontuado.

Sphaerioeme, gen. $\mathrm{n}$.

Espécie-tipo: Sphäerioeme rubristerna, sp. $\mathrm{n}$.

Palpos maxilares pouco mais longos do que os labiais. Lobos oculares superiores com sete fileiras de omatídios, mais afastados entre si do que a largura de um lobo. Antenas com onze artículos; o XI apendiculado (d). Escapo subcilíndrico, tão longo quanto $o$ antenômero IV. Antenômero III com quase o dobro do comprimento do IV, sulcado e carenado. Espinhos antenais curtos em III-V(VI) no macho e em III-VII (₹). Protórax pouco mais largo que longo, desarmado e arredondado aos lados. Pronoto sem tubér culos. Partes laterais do protórax com pontuação sexual. Cavidades coxais anteriores an 
gulosas lateralmente e abertas atrás. Processo prosternal muito estreito. Escutelo glabro. Élitros com apenas pêlos longos; extremidades obliquamente truncadas a levemente entalhadas, desarmadas. Metafêmures lineares, desarmados. Tíbias carenadas. Metatarsômero I mais longo do que II+III.

Discussão. Por apresentar fêmures posteriores sublineares e desarmados, protórax sem tubérculo lateral e espinhos antenais curtos, Sphaerioeme aproxima-se mais de Clausirion e Amethysphaerion. Difere de Clausirion: cavidades coxais anteriores abertas atrás e fortemente angulosas nos lados; palpos maxilares pouco mais longos do que os labiais. Distingue-se de Amethysphaerion: cavidades coxais anteriores angulosas lateralmente; élitros com pêlos abundantés e curtos em toda a superfície.

\section{Sphaerioeme rubristerna, sp. $\mathrm{n}$.}

(Fig. 14)

ठ. Face dorsal preta; face ventral avermelhada; élitros pretos, unicolores ou com quatro manchas amareladas, dorsais (duas antes e duas depois do meio, estas mais obliquas), ou com duas manchas (neste caso, as anteriores ou as posteriores ausentes). Antenas pretas. Coxas, trocânteres e estreita orla da base dos fêmures, avermelhados. Restante das pernas, preto. Fronte, vértice e pronoto fina, densa e rugosamente pontuados, pouco brilhántes. Lados do protórax e prosterno com pontuação sexual densa. Pontos da base dos élitros não ásperos. Mesosterno fina e densamente pontuado. Metasterno e abdômen brilhantes, quase sem pontuação. Fêmures esparsamente pontuados. Antenas atingem o ápice elitral na ponta do antenômero IX, sem pilosidade sexual. Pêlos elitrais numerosos, brancos, curtos, entremeados por poucos pêlos longos. Mesosterno, mesepimeros, mesepisternos e coxas posteriores com pubescência esbranquiçada.

ค. Antenas apenas ultrapassam o ápice elitral. Pontuação das partes laterais do protórax semelhante à do pronoto. Prosterno liso.

Dimensōes, em mm, respectivamente $\delta$ e 9 . Comprimento total, $8,0-11,6$ e 7,013,5; comprimento do protórax, 1,4-2,2 e 1,2-2,4; maior largura do protórax, 1,6-2,4 e 1,3-2,8; comprimento do élitro, 5,6-8,1 e 5,0-9,8; largura umeral, 1,7-2,6 e 1,6-3,2.

Material. Suriname. Marowijne distr.: Anapaike (Rio Lawa), 4 \&, 6 9, XI. 1963, B. Malkin col. (MZSP, parátipos). Brasil. Mato Grosso: Coxim, 18, 1 \&, X.1969, A. Maller col. (DZUP, parátipos); Rio Brilhante, 1 \&, 21-28.X.1970, V. O. Becker col. (DZUP, parátipo). Goiás: Caldas Novas, 1 \%, X.1982, C. Coimbra col. (MZSP, parátipo). Minas Ge rais: Sete Lagoas (IPEACO), 1 \&, 14.II.1959, C. Biezanko col. (DZUP, parátipo); Três Marias, 1 \%, 14.II.1965 (MZSP, parátipo). São Paulo: Araraquara (Rio Jacaré), 1 \%, XI. 1954, Olivastro col., ex-col. J. Lane (MZSP, parátipo). Barueri, 1 ó, 2.XI.1955, K. Lenko col. (MZSP, parátipo). Botucatu, 2 \&, IX.1964, A. Mantovan col. (IBUB, parátipos); 2 \%, X.1964, A. Mantovan col. (IBUB, parátipos); 1 \&, 3.XI.1969, A. Scivittaro col. (MZSP, parátipo); 1 \&, 25.XI.1970, O. J. Chamma col. (MZSP, parátipo); 1 \&, 31.XII.1970, O. Chamma col. (armadilha luminosa) (MZSP, parátipo). Castilho, $3 \delta$, 4 \&, 15-22.IX.1962, Exp. Dep. Zool. col. (MZSP, parátipos); 1 \&, XI.1964, Exp. Dep. Zool. col. (MZSP, parátipo); 2 ठ, 2 \&, X.1964, Exp. Dep. Zool. col. (MZSP, parátipos); $1 \delta, 1$ \&, XI.1964, Exp. Dep. Zool. col. (MZSP, parátipos). Itu, 1 o, U.R. Martins col. (em globo de luz) (MZSP, parátipo); Fazenda Pau d'Alho, 1 o, XII.1958, U.R. Martins cols. (MZSP, parátipo). Piracicaba, 1 dं, 31.X.1969, D. Link col. (DZUP, parátipo). Presidente Prudente, 1 \&, 3.II.1969, A. Scivittaro col. (IBUB, parátipo). Rio Claro, 2 ơ, X.1970, F. Mathiesen col. (MZSP, holótipo, parátipo). Paraná: Porecatu, 39 ơ, 38 \&, 20.X.1970, Becker \& Hatschback col. (DZUP, parátipos). 
Vol. 7(4), 1990

Apoclausirion, gen. $\mathrm{n}$.

Espécie-tipo: Apoclausirion nigricorne, sp. $\mathrm{n}$.

Palpos maxilares pouco mais longos do que os labiais. Lobos oculares superiores com cinco fileiras de omatídios, tão distantes entre si quanto $c a$. três vezes a largura de um lobo. Antenas com onze artículos. Escapo levemente engrossado para o ápice, mais curto que o antenômero IV. Antenômero III ca. um terço mais longo do que o IV, bicarenado e sulcado. Espinhos antenais no ápice intemo de III-VII, gradualmente decrescentes em comprimento. Protórax tão longo quanto largo, desarmado lateralmente, mais constrito na base. Pronoto praticamente sem tubérculos. Partes laterais do protórax com pontuação sexual. Cavidades coxais anteriores não angulosas lateralmente, abertas atrás. Élitros com apenas pêlos longos, esparsos; extremidades cortadas em curva, espinhosas no ângulo externo e denteadas no ângulo sutural. Metafêmures pedunculados e clavados com abas apicais ligeiramente projetadas. Metatarsômero I tão longo quanto II+III.

Discussão. As extremidades dos metafêmures têm abas apicais levemente projetadas e não espinhosas como ocorre em Stizocera, Pantonyssus, Nesostizocera, etc.

Protórax sem tubérculo lateral, metafêmures pedunculados e clavados e pronoto praticamente liso aproximam Apoclausirion de Micropsyrassa, mas neste gênero o protórax é mais longo do que largo, com aspecto cilíndrico. A forma geral do corpo é semelhante à de Clausirion que se distingue de Apoclausirion pelas cavidades coxais anteriores fechadas atrás, palpos maxilares com quase o triplo do comprimento dos labiais e metafêmures engrossados para o ápice.

\section{Apoclausirion nigricome, sp. $\mathrm{n}$.}

(Fig. 13)

d. Colorido geral avermelhado. Escapo avermelhado; antenômeros II-XI pretos, gradualmente mais acastanhados para a extremidade. Extremidades dos fêmures, tíbias e tarsos, pretos. Vértice com pontuação rasa, moderada. Pronoto com raros pontos. Partes laterais do protórax com pơntuação sexual que não atinge o pronoto. Élitros com pontos ásperos na base, marcados até o nível do meio. Prosterno com pontuação sexual. Mesepimeros, mesepisternos e metepimeros esparsamente pubescentes. Fêmures e restante da face ventral, lisos. Pélos esparsos por todo o corpo, nos élitros entremeados por outros muito alongados. Antenas atingem o ápice elitral no meio do antenômero IX.

Dimensões, em mm. comprimento total, 9,3; comprimento do protórax, 2,0; maior largura do protórax, 2,0; comprimento do élitro, 6,5; largura umeral, 2,3.

Material. Brasil. Mato Grosso: Diamantino (Fazenda São João), 1 ठ, X.1981, Furtado col. (MZSP, holótipo, doação de K. E. Huedepộhl). 
Revta bras. Zool.

\section{REFERÊNCIAS}

BATES, H.W., 1867. New genera of longicorn Coleoptera from the River Amazons. Ent. Montl. Mag. 4: $22-28$.

BATES, H.W., 1870. Contributions to an insect fauna of the Amazon Valley (Coleoptera: Cerambycidae). Trans. Ent. Soc. London 1870: 243-335.

GILMOUR, E.F., 1963. Some Caribbean Coleoptera Cerambycidae. Stud. Fauna Cur. Carib. Is. 18 (78): $75-102$.

MARTINS, U.R. \& M.A. MONNE, 1975. Longicórnios da Coleção Hüdephol I (Coleoptera, Cerambycidae). Pap. Avulsos Zool., São Paulo, 28 (16): 269-293.

MELZER, J., 1931. Longicorneos americanos principalmente do Brasil, novos ou pouco conhecidos. Arch. Inst. Biol. São Paulo 4: 51-82.

NAPP, D.S. \& U.R. MARTINS, 1982. Mephritus Pascoe, 1866 (Coleoptera, Cerambycidae); revalidação do gênero, chave para espécies, notas sinonímicas e descriçōes. Revta. bras. Ent., São Paulo, 26 (1): 75-86.

WHITE, A., 1853. Catalogue of the coleopterous insects in the Collection of the British Museum, vol. 7, London, 174 pp., 4 est. 